\title{
Beyond the Psychoactive Effects of Ayahuasca: Cultural and Pharmacological Relevance of Its Emetic and Purging Properties
}

\author{
Authors \\ Matteo Politi ${ }^{1,2}$, Giorgia Tresca ${ }^{1}$, Luigi Menghini ${ }^{1}{ }^{\mathbb{D}}$, Claudio Ferrante $^{1}$ \\ Affiliations \\ 1 Department of Pharmacy, Botanic Garden "Giardino dei \\ Semplici”, Università degli Studi “Gabriele d'Annunzio”, \\ Chieti, Italy \\ 2 Research Department, Center for Drug Addiction Treat- \\ ment and Research on Traditional Medicines - Takiwasi, \\ Tarapoto, Peru
}

\author{
Key words \\ Banisteriopsis caapi, Psychotria viridis, Malpighiaceae, \\ Rubiaceae, Ayahuasca, traditional Amazonian medicine, \\ emetic, purgative \\ received \\ June 7, 2021 \\ accepted after revision \\ October 6, 2021 \\ published online \\ November 18, 2021
}

\section{ABSTRACT}

The herbal preparation ayahuasca has been an important part of ritual and healing practices, deployed to access invisible worlds in several indigenous groups in the Amazon basin and among mestizo populations of South America. The preparation is usually known to be composed of two main plants, Banisteriopsis caapi and Psychotria viridis, which produce both hallucinogenic and potent purging and emetic effects; currently, these are considered its major pharmacological activities. In recent decades, the psychoactive and visionary effect of ayahuasca has been highly sought after by the shamanic tourism community, which led to the popularization of ayahuasca use globally and to a cultural distancing from its traditional cosmological meanings, including that of purging and emesis. Further, the field of ethnobotany and ethnopharmacology has also produced relatively limited data linking the phytochemical diversity of ayahuasca with the different degrees of its purging and emetic versus psychoactive effects. Similarly, scientific interest has also principally addressed the psychological and mental health effects of ayahuasca, overlooking the cultural and pharmacological importance of the purging and emetic activity. The aim of this review is therefore to shed light on the understudied purging and emetic effect of ayahuasca herbal preparation. It firstly focuses on reviewing the cultural relevance of emesis and purging in the context of Amazonian traditions. Secondly, on the basis of the main known phytochemicals described in the ayahuasca formula, a comprehensive pharmacological evaluation of their emetic and purging properties is presented.

\section{Introduction}

Ayahuasca is a traditional psychoactive herbal medicine with a long history of use in South America, especially in the Amazonian basin [1,2], and with promising pharmaceutical potential in modern biomedical context [3-7]. The word ayahuasca comes from the Quechua language and can be translated as "the vine of the soul" or "the vine of death"; this brew is also known by several other names such as yage, hoasca, or caapi [8]. This name can refer to a single plant species, the vine Banisteriopsis caapi (Spruce ex Griseb.) Morton (Malpighiaceae), rich in $\beta$-carboline alkaloids [9], but it is usually associated with a mixture of $B$. caapi and Psychotria viridis Ruiz \& Pav. (Rubiaceae), the latter rich in DMT (N,N-dimethyltryptamine) alkaloid [10]. Other admixture plants, however, can be also added into this mixture, but the most common names still remain the same [11-14]. Recently, especially in the context of the ayahuasca internationalization, other non-traditional plants are being used to create the so-called "ayahuasca analogues", including other Banisteriopsis and Psychotria species $[15,16]$ or, in general, other plant sources containing $\beta$-carboline and DMT [17-19]; these alkaloids are considered responsible for the main pharmacological activity of ayahuasca [20,21]. This work focuses on ayahuasca as commonly known in the scientific literature; therefore, a plant mixture made of $B$. caapi and $P$. viridis, 


$\begin{array}{ll}\text { ABBREVIATIONS } \\ \text { 5-HT1A } & \text { 5-hydroxytriptamine 1A receptor } \\ \text { 5-HT1B } & \text { 5-hydroxytriptamine 1B receptor } \\ \text { 5-HT1C } & \text { 5-hydroxytriptamine 1C receptor } \\ \text { 5-HT1D } & \text { 5-hydroxytriptamine 1D receptor } \\ \text { 5-HT2A } & \text { 5-hydroxytriptamine 2A receptor } \\ \text { 5-HT2C } & \text { 5-hydroxytriptamine 2C receptor } \\ \text { 5-HT3 } & \text { 5-hydroxytriptamine 3 receptor } \\ \text { 5-HT4 } & \text { 5-hydroxytriptamine 4 receptor } \\ \text { 5-HT6 } & \text { 5-hydroxytriptamine 6 receptor } \\ \text { 5-HT7 } & \text { 5-hydroxytriptamine 7 receptor } \\ \text { CTZ } & \text { chemoreceptor trigger zone } \\ \text { DMT } & \text { N,N-dimethyltryptamine }\end{array}$

although some considerations will be provided also for certain analogue preparations.

Indigenous people in South America have used ayahuasca for centuries, and the ceremony associated with its consumption has become common among the mestizo populations in urban areas of the Amazon [22, 23]. In particular, a few decades ago the ayahuasca ritual became important in several Amazonian areas as a cure for drug addiction [24-27]. More recently, it is gaining further attention as a treatment for other mental health disorders [28-32]. This trend is boosted from local consumption in the Amazonian basin to a global phenomenon, with a continued increase in scientific publications in recent years. Despite the emphasis on the psychoactive effects of ayahuasca and its potential application in mental health disorders, the scientific community seems to pay less attention to its purgative and emetic properties, the latter only scarcely mentioned and mainly considered as side and undesirable effects $[33,34]$. Within the traditional or ritual use, however, such purgative and emetic effects are considered relevant aspects for the overall efficacy of the ayahuasca treatment [35-37]. This work, therefore, aims to review the cultural significance of these effects within the traditional and ceremonial use of ayahuasca, and to review the pharmacology of the main constituents for their potential application in gastrointestinal health.

The searches for bibliography were performed on Scifinder ${ }^{n}$, Pubmed, Web of Science and Google Scholar and the main search words and terms applied were "ayahuasca”, "Banisteriopsis caapi”, and "Psychotria viridis". As of March 22th 2021, from Scifinder", the term 'ayahuasca' highlights 408 references, which includes 78 reviews. The term Banisteriopsis caapi results in 182 references, and Psychotria viridis 185, although in both cases some references are the same identified using the term ayahuasca. With the present review a narrative one (and not systematic), a manual search on the cultural and pharmacological significance of purgative and emetic effects of ayahuasca was undertaken using the overall selected publications. Due to the large number of publications, additional keywords to search within the results were used, including "emesis, emetic, vomiting, purge, purging, purgative, cleansing, detoxifying". All studies mentioning such kind of effects, either from cultural as well as clinical and pharmacological aspects, were carefully revised and cited if considered relevant for the purpose of the present review. Other studies including those describing the phytochemical profiles of the plants used to prepare ayahuasca and the very same ayahuasca herbal preparation, were also used to describe the overall chemical composition of this remedy; this was necessary address the pharmacology aspects of ayahuasca. In fact, in this latter case, the literature search focused mainly on the single molecules contained in ayahuasca, their role in gastrointestinal health and how this is related to mental health. Additionally, the bioinformatics platform SwissTargetPrediction (http://www.swisstargetprediction.ch/) was used to predict putative targets underlying the emetic effects induced by the main components of ayahuasca. Specifically, the putative targets were predicted based on the structure of the main phytochemicals present in the herbal preparations ( $\beta$-carboline alkaloids), and the components-targets plot was built through Cytoscape software, version 3.8.

\section{The Cultural Role of Purgative and Emetic Effects in the Use of Ayahuasca}

\section{The close relation between ayahuasca's purgative and visionary effects}

Beyer reports that in the Amazon, vomiting is intrinsically part of life and is not considered as symptom or a sickness; it is part of learned behaviors [11]. Within the mestizo ${ }^{1}$ population, in the vegetalista ${ }^{2}$ tradition, a rather common name for ayahuasca is, in fact, purga, (purge) and the healer administering it, may be referred to as the purguero [38]. Similarly, in the indigenous Amazonian Matsinenga language, ayahuasca is called kamarampi, which means "remedy for vomiting" [39]. In a study conducted in Chazuta, Peru, ayahuasca has been reported to fulfil a poorly ritualized and predominantly purging role [35]. It has been argued, too, that ayahuasca's primary and original function in the Amazonian pharmacopeia was in fact for gastrointestinal health [40], as purgative plants are a popular way of dealing with parasitic infections [11]. According to research among mestizo shamans, Luna points out that ayahuasca's efficacy is related to its ability to produce visions, as much as to its ability to induce vomiting and diarrhoea - so much so that when it does not fulfil one of these two functions, it is in fact considered to be a bad medicine [41]. The known effect of mareación, which refers to the dizziness, nausea, and vomiting the ayahuasca preparation provokes, is strictly linked to the teaching qualities of plant teachers used by healers [41]. Furthermore, these physical purging ${ }^{3}$ symptoms often converge with the visionary ones: vomiting may occur when visions become very intense, and purging may actually be a necessary

Mestizo refers to the population of mixed heritage and which does not identify as indigenous.

2 Vegetalista refers to Peruvian mestizo individuals who carry out healing practices, with an indigenous origin, focused on the use of plants.

3 With purging we refer to both the emetic and laxative effects of ayahuasca which are often accompanied by a larger body of symptoms such as yawning, burping, sweating, and participating a more general cleansing process. 
process to undergo in order to have positive experiences and visions $[42,43]$. The ritualized chants, known as icaros, which accompany the experience of ayahuasca production and intake, may be, in fact, precisely intended to trigger or reinforce the previously mentioned state of mareación [41].

In various South American indigenous health cosmologies, illness may very well be seen to be caused by harmful spirits or by the presence of objects or spirits trapped in the body [44]. Vomiting expels intruding entities from the body, ridding it from illness [45]. Moreover, this cleansing process might be necessary to establish contact with spirit allies and plant spirits [39]. As the purgative and emetic effects of ayahuasca are used to cleanse spiritual intrusions, visions are a way for the drinker to travel to the spiritual world to harmonize relations and cosmological imbalances for the restoration of health [44]. However, this may not take place solely for healing purposes. Hunters, for example, may use emetic plants to cleanse bad spirits in their body and, through the psychoactive effects, they may visit the spiritl world to negotiate game animals of the forest [39]. Initially, plants with emetic and laxative properties are administered regularly to facilitate the encounter with frightening underworld beings, difficult sensations, and emotions, to cleanse spiritual impurities and prepare the initiates to meet with the spirit world of plants [46]. This also reinforces the link between the purgative and visionary effects of plants in shamanic contexts.

\section{The healing-related role of purging in contemporary ayahuasca settings in the Amazon and abroad}

Peruvian indigenous Amazonian shamanism and the use of ayahuasca have been generated and shaped through contact and exchange with nearby and foreign cultures across the centuries. An attempt to retrieve its authenticity or its traditional meanings may prove difficult [47], whereas delineating how its ritual practice is being constructed in response to the needs and expectations of its present participants may be more realistic $[48,49]$.

As illustrated by Labate [47], in contemporary settings, ayahuasca use is increasingly being formulated as a therapeutic response to the needs of the "modern self", to acquire deeper understanding of oneself and participate in the development of personal identity. Psychological language and narratives thus permeate these experiences, and ayahuasca becomes instrumental to the processing of trauma [47]. Elements which were traditionally embedded in indigenous spirituality and ayahuasca use, belonging, for example, to larger processes of cosmic creation and cultural and environmental regeneration are often marginalized, excluded from western understandings and experiences [49].

Within this neo-shamanic context, therefore, both in the Amazon and abroad, the meaning and act of vomiting and purging more generally also becomes porous to adjustment, as it is not widely practiced in the contemporary Western healing tradition [37]. Fotiou and Gearin report that in rare cases, vomiting may not be considered a prerogative for healing, or as something to practice outside of the ceremony circle [37]. Labate argues that vomiting may, in some instances, be seen as a by-product, a prerequisite "for the nobler visionary end" [47]. Moreover, as simply stated by Beyer, vomiting is distressing to a Westerner, who usually considers it humiliating [11].
Nevertheless, ayahuasca is, in many cases, sought out by people who are not satisfied with the reductive approach of biomedicine and are in search of alternative therapies that holistically respond to Western individuals' needs to address healing for the body, mind, and soul [50]. Fotiou and Gearin, who to our knowledge produced the only study on this topic, make the point that in contemporary ayahuasca contexts, purging is not merely a physical act, but is dense with meaning [37]. Furthermore, it has been reported to be understood as being related to the healing process $[37,47,50]$. Some ayahuasca users report what they call a psychic purging [49] to begin, even before consuming the beverage. in. In the reviewed literature to follow, it appears that vomiting plays an active role in the various dimensions of the healing narratives of healers and patients, playing a fundamental role in the production of ayahuasca's efficacy.

The experience of vomiting may certainly be reframed through a new psychological lens and a new understanding of healing [37]. For example, given the popular Western interest in ayahuasca shamanism for mental healing and personal development purposes, difficulties encountered during the rituals are perceived as personal blockages rather than, for example, the product of sorcery, as they might have been in indigenous settings [47]. Purging is known to be a necessary process to expelemotions and states of being which put a strain on the person, feelings of emptiness, or the weight of past traumatic events [51]. Fotiou and Gearin cite Ismael Apud, in referring to "the basic psychological-bodily mechanism of contents expulsion" [52] when visions become too much to handle [37]. As ayahuasca results in confrontation with one's emotions and fears, vomiting, along with other somatisizations, are ways of purging such feelings and producing relief [3]. Gearin sustains that "psychic-bodily residues" of types of social victimization appear to be the most common content that users described purging" [51], a way to relive and expel past painful experiences and in so doing, heal trauma. Emesis, along with other bodily sensations, are therefore significantly intertwined to healing and the visionary experience [37].

Vomiting and purging might be perceived as a required step to find one's life path [37], process difficult emotions, contact the unconscious, or "expiating immoral behaviour" [47]. Yet Fotiou and Gearin also report how a North American shaman frames the perception of negative thoughts and feelings arising as bad spirits leaving the body [37]. Purging provides a visible sign of a healing, and the notion of cleansing extends to physical and emotional but also spiritual levels [50]. As documented by Berlowitz, emetic plant rituals are seen to release negative physical, emotional, and spiritual layers [53]. Shamanic practices may very well converge with Western ideas of spirituality [37] and influence one another [47]. Furthermore, people may acquire new perspective or awareness on the relation between the physical and spiritual world [37] and vomiting, for example, may become an avenue to release spiritual entities from the body in contemporary ayahuasca contexts [51].

Vomiting definitely appears to also hold a social valence within the context of healing. Through synesthetic avenues, the act and sound of vomiting may diffuse across the social field of the ritual circle and influence other participants' visions and experience [51]. Moreover, ayahuasca's emetic properties are confined not 
only to the expulsion of personal individual trauma, but also to social ills and social trauma [51]. Patients, for example, referred to purging for psychic sicknesses of other people; for example, Indian women who have been sexually abused or the experience of indigenous people [37]. They mentioned purging and releasing what are considered to be toxic modern lifestyles such as pharmaceutical drugs, electro-magnetic radiation, the media, processed foods etc. [51]. Therefore, the act of purging may inform or generate different outlooks on social life and the healing intentions of people expand beyond their individual concerns towards broader social issues and surface in visions that are mediated by the bodily act of vomiting [37].

As highlighted by Fotiou and Gearin, despite many elements and complexities of indigenous Amazonian shamanism clearly have not been integrated in neo-shamanic contexts, purging may still carry the function of liberating the body from unhealthy emotional baggage; in addition, vomiting appears to be rather crucial in contextualizing ayahuasca efficacy, not only from a personal and individualistic healing standpoint, but expanding to include social and spiritual dimensions [37].

\section{Ayahuasca Phytochemical Profiles}

$\beta$-carboline alkaloids including harmine, harmaline, and tetrahydroharmine from $B$. caapi, together with DMT from $P$. viridis are all well-known alkaloid compounds in ayahuasca, and most of the analytical methods focus on their qualitative and quantitative determination [54-56]; dedicated methodologies for these different classes of alkaloids are sometimes separately implemented $[57,58]$, as well as their detection in human bio-fluids $[59,60]$.

Quantitative variations of such alkaloids in the plant material, depending on the geographical origin or the harvesting time, have been investigated [61]. In particular, the comparison of 33 samples of $B$. caapi and 37 samples of $P$. viridis collected in the same day in 22 different location in Brazil indicated the range of harmine between $0.31-8.43 \mathrm{mg} / \mathrm{g}$ of dried plant material, harmaline $0.03-0.83 \mathrm{mg} / \mathrm{g}$, tetrahydroharmine $0.05-2.94 \mathrm{mg} / \mathrm{g}$, and DMT $0.00-17.75 \mathrm{mg} / \mathrm{g}$; moreover, the circadian fluctuations of DMT in a single living plant of $P$. viridis was measured over $21 \mathrm{~h}$ at $3 \mathrm{~h}$ intervals, allowing the detection of a range between 5.4$9.6 \mathrm{mg} / \mathrm{g}$ of dried leaves [61]. More recently, other authors provided an extended investigation of a large number of wild $B$. caapi samples and reported the alkaloids' content in the methanol extract in the range of $<0.001-18.27 \mathrm{mg} / \mathrm{g},<0.003-2.08 \mathrm{mg} / \mathrm{g}$ and $<0.0007-29.04 \mathrm{mg} / \mathrm{g}$ for tetrahydroharmine, harmaline, and harmine, respectively. This highlights the high quantitative variability (respective mean values are $2.18,0.45$ and $4.79 \mathrm{mg} / \mathrm{g}$ ); such quantitative variability could be related, at least partially, to the geographical origin and to differences between wild and cultivated plants, whereas other factors like collecting season, stem diameter, or place of collection are not critical [62]. The phytochemical profile of the traditionally prepared ayahuasca reflects the plant composition and confirms the presence of 1.16, 0.19 and $1.28 \mathrm{mg} / \mathrm{mL}$ of tetrahydroharmine, harmaline, and harmine expressed as mean values (concentration ranging from < $0.09-$ $3.05 \mathrm{mg} / \mathrm{g},<0.01-0.95 \mathrm{mg} / \mathrm{g}$ and $<0.11-7.11 \mathrm{mg} / \mathrm{g}$, respectively), thus confirming the presence of DMT as the result of the inclu- sion of $P$. viridis as an ingredient (mean concentration $1.08 \mathrm{mg} / \mathrm{mL}$ in a set of 33 ayahuasca samples) [62].

The above-mentioned quantitative data therefore agreewith other investigations that are more focused on the phytochemical analysis of the finished product - the ayahuasca herbal preparation. For example, the various alkaloids' profiles of 29 samples of ayahuasca herbal preparation resulted in different cultural contexts including the religious groups Uniao do Vegetal, Santo Daime, and Barquinha, originating in Brazil during the twentieth century [63], as well as the indigenous group of Shuar from Ecuador has been described by Callaway [64]; within the whole samples analyzed, the concentration of harmine ranged from 0.45 $22.85 \mathrm{mg} / \mathrm{mL}$, harmaline $<0.01-0.9 \mathrm{mg} / \mathrm{mL}$, tetrahydroharmine $0.48-23.8 \mathrm{mg} / \mathrm{mL}$, and DMT $0.00-14.15 \mathrm{mg} / \mathrm{mL}$. Although the number of samples from each group were not the same, and therefore it is impossible to apply a proper statistical comparison, it would appear that the Uniao do Vegetal samples are more diluted compared with the others. This data is also observed in another study [54] focused on 38 ayahuasca samples obtained from the group Uniao do Vegetal, measuring the range in concentration of harmine as $0.41-1.82 \mathrm{mg} / \mathrm{mL}$, harmaline $0.04-0.42 \mathrm{mg} /$ $\mathrm{mL}$, tetrahydroharmine $0.40-3.31 \mathrm{mg} / \mathrm{mL}$, and DMT $0.06-$ $0.34 \mathrm{mg} / \mathrm{mL}$ ). It is noteworthy, however, that the highest DMT concentration $(14.15 \mathrm{mg} / \mathrm{mL})$ was detected in one of the three Santo Daime samples, followed by the only Barquinha sample analyzed $(12.67 \mathrm{mg} / \mathrm{mL})$, then in one of the twenty Uniao do Vegetal samples $(5.84 \mathrm{mg} / \mathrm{mL})$, and lastly in one of the five Shuar samples $(4.12 \mathrm{mg} / \mathrm{mL})$; on the contrary, the highest whole $\beta$-carboline alkaloids concentrations were detected in four of the five Shuar samples. This could reflect the central role of $B$. caapi and its $\beta$-carboline alkaloids in the indigenous context compared with the more recent ayahuasca preparations which appear to be richer in the visionary and hallucinogenic DMT. With the emetic and purgative effects mainly due to the presence of $B$. caapi [14], such quantitative phytochemical data could therefore reflect the relevance of this kind of pharmacological activity in traditional contexts compared to modern ones. Although few other analyses on real ayahuasca samples are seen in the literature [65-67], they do not contribute additional information in this regards, and further investigations are therefore necessary to better link the phytochemical profiles of consumed ayahuasca with clinical data.

Laboratory arrangement of the ayahuasca herbal preparation [68] and full secondary metabolite analysis of $B$. caapi and $P$. viridis showed a broader picture of the alkaloids beyond the four major ones discussed above, as well as different classes of compounds. Beyond DMT, P. viridis also shows N-methyltryptamine and 2-methyl-1,2,3,4-tetrahydro- $\beta$-carboline [69], with other common secondary metabolites including squalene, sitosterol, stigmasterol, ursolic acid, and oleanolic acid [70]. Beyond harmine, harmaline, tetrahydroharmine $B$. caapi contains lesser amounts of harmol, harmalol, norharmane, banistenoside $A$ and $B$, procyanidin B2, epicatechin, and other common secondary metabolites as reported by Wang et al. [58]. A relevant variable to be considered in the phytochemical description of the ingredients and the ayahuasca preparation is the origin of the sample. When powdered plant materials or the herbal preparation are acquired from a physical or the web market, the identification of original ingre- 
dients is not possible, and in order to make the products stronger or make them more appealing for customers it should be taken into consideration that effects of adulteration and sophistication cannot be excluded. This likely applies, for example, in the case described by Simão et al. [71] in which a commercial sample of $P$. viridis contains more $\beta$-carboline alkaloids than DMT. The full LC-MS analysis of this work describes also different classes of phenolic compounds, but due to the possible sophistication, the usefulness of this phytochemical fingerprint remains unclear. A similar approach for the determination of the phenolic profiles of $B$. caapi and P. viridis is described by Gonçalves et al. [72]; both botanical materials, however, have been acquired from the same online shop as for the case of Simão et al. [71] Further investigations to determine the full secondary metabolite fingerprints contained especially in the real sample of ayahuasca herbal preparation appear to be therefore still necessary. Analytical measurements of the major alkaloids were also performed in other plant species used in ayahuasca analogues [62]; this topic, however, remain outside of the scope of the present article.

The change in the concentration of the major alkaloids in the ayahuasca preparation in relation to the decoction time applied during the preparation was measured [73]. Harmine, harmaline, tetrahydroharmine, harmalol, and DMT concentrations in the samples ranged from 0.3 to $36.7 \mathrm{mg} / \mathrm{mL}$; this confirms that the cooking time is a preparation step that affects the overall alkaloid concentration. This kind of phytochemical consideration, together with those above-mentioned. are more related to the quality of the plant materials, indicate the necessity of deep knowledge of $B$. caapi and $P$. viridis as well as the very same mode of dressing of the ayahuasca herbal preparation to obtain a high-quality herbal product. This knowledge is certainly part of the heritage of indigenous peoples who for many centuries have been able to distinguish dozens of different "types" of liana (B. caapi), or to select the best leaves from chacruna ( $P$. viridis) within one of the most biodiverse environments in the world. This may be related to the development and plant phenological stage that are also also discriminant for different uses; the origin of this kind of traditional knowledge, however, seems to still be mostly unknown. In fact, by listening to the same voice of the local healers, the plants become the teachers of such knowledge, and the way to prepare a good quality herbal medicine is indicated directly by the vegetable entities. The concept of plants as teachers is present in the ethnopharmacology literature, thanks to the anthropologist Luis E. Luna $[38,74]$. In this work, a particular traditional Amazonian medicinal practice called la dieta (the diet), is clearly indicated as the main tool for acquiring a comprehensive know-how on plant medicine, including the correct herbal mode of preparation. Although la dieta is a fundamental Amazonian traditional tool for alarming diseases and for shamanic apprenticeship, it has taken some decades for other researchers to further mention and describe it scientifically $[46,75,76]$. Additional studies on la dieta have increased in recent years [77-80]. Thiss seems to be the correct way to try to interpret the claims of indigenous people in the Amazon regarding the acquisition of their herbal medicinal knowledge directly from plants. Despite the recent advances in plant biology that recognize a degree of intelligence in the plant kingdom [81-83], and a consequent argument about the possibility of human-plant interactions in accord with the above-mentioned Amazonian indigenous knowledge [84], the fact that is possible to learn directly from plants could remain difficult to be fully scientifically validated. Certainly, it is already clear that the chemistry of a finished herbal product can be strongly influenced by following certain traditional pharmaceutical practices; this has been observed for Chinese herbal medicine processing methods (Paozhi) such as burning, calcining, stewing, and soaking [85,86], as well as in the case of Amazonian herbal medicine preparations which are often characterized by long decoction time [87]. A lot remains to be done, however, concerning the scientific validation of other traditional practices that fall outside current scientific understanding, including blowing tobacco smoke or chanting sacred melodies (icaros) on the plant remedy to influence its properties, although those are common practices within the Amazonian pharmaceutical tradition [88]; these could represent therefore important research topics for the new generation of experts in phytochemistry and pharmacognosy.

\section{The Pharmacology of Ayahuasca Preparations}

\section{Emesis and purging: problem or solution?}

Within the modern biomedical approach, purging and emesis are usually considered more physiopathological conditions that require specific treatments $[89,90]$ rather than therapeutic tools [91]. In different traditional medicinal contexts they are actually representing important detoxification strategies, often practiced in combination with the use of medicinal plants; this is the case, for example, of the famous pancha karma therapy belonging to the Ayurveda tradition in India [92] or of a Buddhist drug rehabilitation program in Thailand [93], but also of laxative herbal treatments belonging to the traditional Chinese medicine [94] or Japanese kampo [95]. Several examples of purging practices associated with traditional Amazonian herbal medicine have been previously described $[35,46]$, although animal drugs are also used for similar purposes [96]. In this context it is worth mentioning that a liquid preparation of tobacco is still used as an important herbal purge [97], and similarly, in this case the tobacco enema, was also part of the western medical tradition [98]. It seems therefore that emesis and purging are still sitting on a subtle border between being considered problem or solution. In this regard, it is noteworthy to mention how emesis is a key protective reflex, involving multiple systems, including respiratory, gastrointestinal, and abdominal muscles, serving also as a potential therapeutic option, especially towards food toxin ingestion and migraine attack [91]. It is also frequently used by bulimics as a questionable "self-made remedy" to control body weight gain [91]. In this regard, it is also sensitive to highlight the neurotransmitter and peptide pathways common to both emesis and appetite control. Specifically, serotonin, deeply involved in suppressing food intake in the hypothalamus [99], mediates emesis stimulus in the chemoreceptor trigger zone (CTZ) [91]. In analogy, gut-deriving peptides involved in the hypothalamic short-term control of energy balance [99] are also able to signal emetic stimulus in the CTZ. The rationale for such interactions is the lack of a complete blood brain barrier in both hypothalamus, particularly in the arcuate nucleus, and CTZ, thus 
permitting the delivery of these substances from periphery to CNS, and therefore suggesting a pivotal role of their in protecting human body against xenobiotic poisoning.

Significant adverse effects after consumption of classic psychedelics, mainly when used as pure drugs in controlled clinical studies, are rare; however, when consumed in unsupervised settings, the judgement of individuals can be compromised, often resulting in what are called "bad trips", characterized by symptoms like anxiety, palpitations, and visual distortions [100]. By virtue of MAO inhibition, severe adverse effects can occur when ayahuasca or the $\beta$-carbolines alone are used concomitantly with selective 5-HT reuptake inhibitors such as antidepressants, resulting in a potentially fatal condition known as 5-HT syndrome [101]. Vomiting and diarrhoea are often reported as adverse effects resulting from ayahuasca consumption [102] but, again, this seems to largely depend on the context of use. In fact, in another study conducted on depressive patients, the emetic effect was not considered a cause of discomfort [103]. Self-induced vomiting, especially in a context of pathological condition as for the case of bulimia nervosa, can trigger several medical manifestations that affect nearly every organ system in the body; effects range from superficial skin and dental findings to esophageal pathology, electrolyte abnormalities, cardiac arrhythmias, and in extreme cases, death [104]. On the other hand, the same practice of vomiting, as earlier mentioned, is an important aspect of traditional Amazonian medicine, where emetic plants labelled as "medicinal stressors", are used for depurative purposes not only to restore health but also to maintain it [35]. In our understanding, the key factor that defines emesis and purging as a problem or a solution (but this likely also applies to the use of psychedelics at large) is therefore the context of use, often related to cultural context. Western culture will probably benefit from further studies of those cultures like the Amazonian one, where know-how on emesis and purging is still in use as a therapeutic option. The etymology of the word "pharmakon" from ancient Greek means at the same time "poison" and "drugs"; this remarks the subtitle line between being a problem or a solution and the pharmacist's ability to convert a potential poison into an effective drug.

\section{Biochemical aspects of purgative and emetic effects}

The main pharmacological activities of ayahuasca are known [69, $72,105]$; some of them, especially due to the $\beta$-carboline alkaloids, induce gastrointestinal effects $[106,107]$. In this regard, the stimulation of serotonin-mediated vagal pathways could be induced by the $\beta$-carboline alkaloids harmine, harmaline, and tetrahydroharmine [108] ( $\triangleright$ Fig. 1). It has been reported that these phytochemicals could induce intoxication, following oral administration of herbal preparations obtained from different plant species, such as of Peganum harmala, collectively known as "ayahuasca analogues": the intoxication is characterized by different clinical symptoms such as visual and auditory hallucinations, locomotors, ataxia, nausea, vomiting, confusion, and agitation [109]. The pharmacological mechanisms underlying these effects could be ascribed to the multidirectional stimulation of serotonin pathway. Besides being well-known MAO-inhibitors, these phytochemicals are also predicted to interact with a huge number of proteins, including serotonin receptor subtypes 5-HT2A, 5-HT2C, 5-HT7,

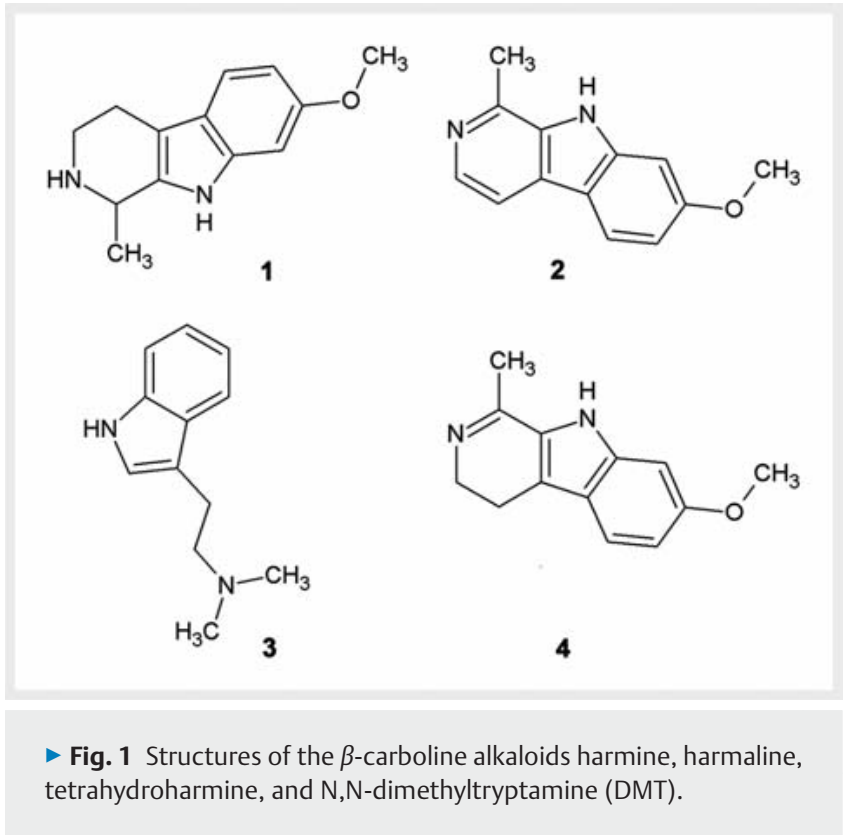

5-HT6 ( $\bullet$ Fig. 2). Among them, the sole 5-HT2A was reported to be expressed at both peripheral and central levels, and it has been described a key role of this receptor in regulating appetite control in the hypothalamus. The $5-\mathrm{HT} 2 \mathrm{C}$ receptor was also implicated in food intake control. Overall, the role of the $5-\mathrm{HT} 2 \mathrm{C}$ and $5-\mathrm{HT} 2 \mathrm{~A}$ receptors in food intake could depend on their interactions with hypothalamic first-order neuron-deriving peptides in the arcuate nucleus [110], which is also targeted by gut-deriving peptides acting as short-term satiety signals [99] (i.e. peptide YY, glucagonlike peptide 1). However, multiple studies suggest emetic effects related to the activation $5-\mathrm{HT} 2 \mathrm{~A}$ receptor $[111,112]$. The emesis induced by mycotoxins has also been recently associated with the increased plasma levels of both peptide YY and 5-HT [113]. It is important to highlight that 5-HT, besides acting as a neurotransmitter in the brain, functions as a mitogen and pro-inflammatory factor, particularly in the gut, which synthesizes most of 5-HT pool [114]. Conversely pro-inflammatory stimuli were reported to increase gut 5 -HT levels $[115,116]$. Ayahuasca is also known for containing the serotonergic 5-HT2A agonist DMT [117], whereas docking runs also suggest putative interactions of the aforementioned $\beta$-carboline alkaloids and DMT with the 5 -HT2A receptors ( $\vee$ Fig. 3), thus further supporting the involvement of these compounds in the emetic and purgative effects induced by traditional preparations of ayahuasca [118]. Specifically, the levels of these alkaloids in ayahuasca water extracts $(27-2000 \mu \mathrm{g} / \mathrm{mL})$ [108] agree with the putative micromolar affinities of the same compounds towards $5 \mathrm{HT} 2 \mathrm{~A}$ receptors. Therefore, further pharmacological studies need to advance our understanding of the role of serotoninergic system in the emetic and purgative effects induced by ayahuasca. Nevertheless, the very similar affinities displayed by these compounds towards the 5 -HT2A receptors permit a hypothesis of their involvement in the emetic and purgative effects induced by ayahuasca preparations, thus partly explaining the similar effects of different preparations of ayahuasca not always traceable, to some plant mixtures used in the preparations of tra- 


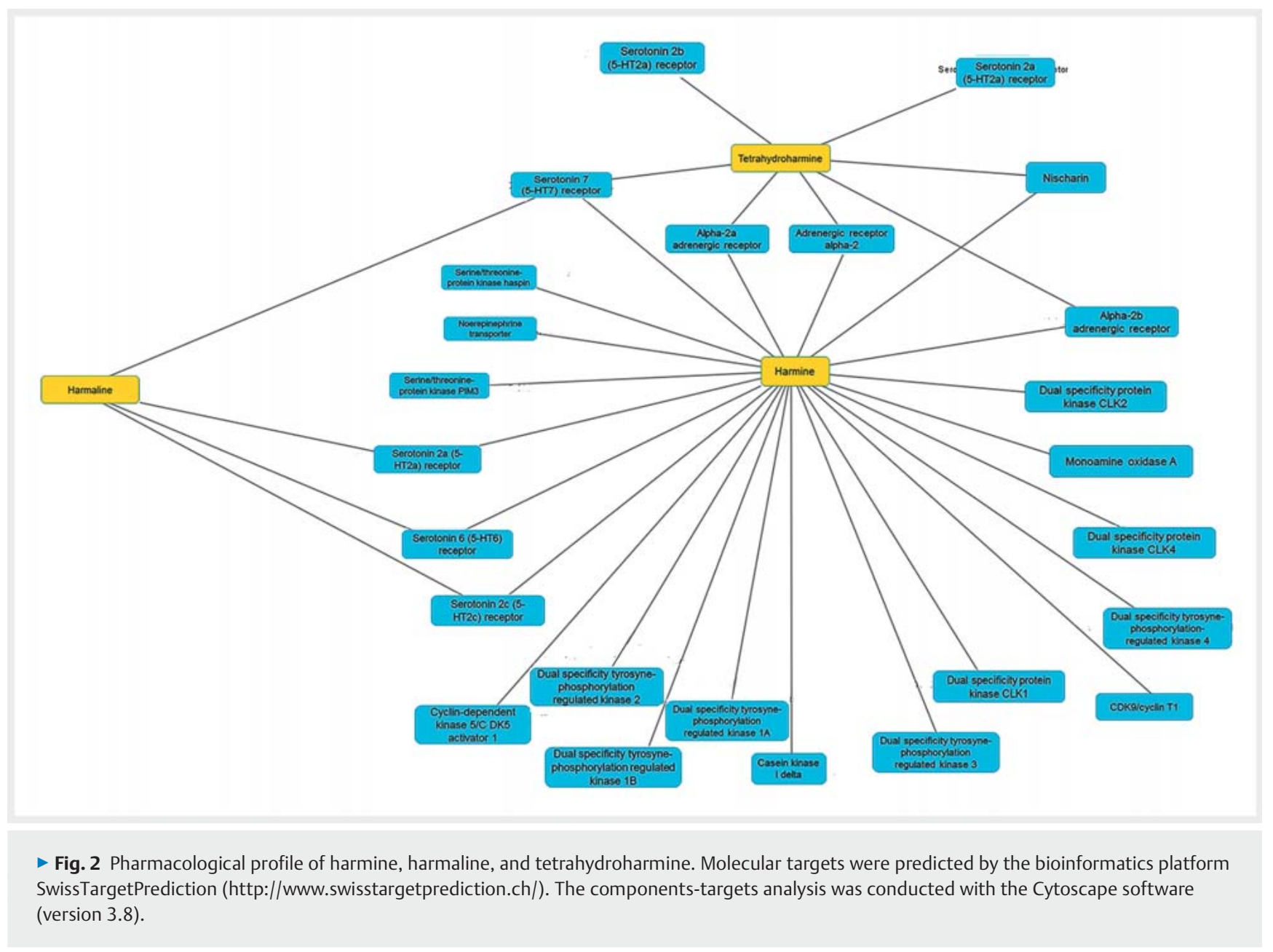

ditional remedies. However, we cannot exclude that these alkaloids could target other serotonin receptors, including 5-HT1A, 5-HT1B, 5-HT1C, 5-HT1D, 5-HT4, and above all, 5-HT3, this last being deeply involved in the induction of emesis [119].

\section{The Role of Gut Microbiota in Relation to Mental Health}

The gut microbiota also seems to have an influence in the development of various diseases of the central nervous system, including motility and behavioral disorders, neurodegenerative diseases, cerebrovascular accidents, and neuroimmune-mediated disorders [120]. Scientific studies have highlighted a direct correlation between the intestinal microbiota and the brain, establishing the existence of the so-called gut microbiota-brain axis, identifying different pathways of communication along this axis including those driven by the immune system, the vagus nerve, or by modulation of neuroactive compounds by the microbiota [121]. Gut bacteria have been discovered to possess the ability to produce and manipulate several neurotransmitters including serotonin, dopamine, acetylcholine, GABA, and more. Although the direct pharmacological effects of psychedelics on bacteria are understudied, the emotional and psychological benefits of psy- chedelics may indirectly alter microbial communities in the gastrointestinal tract via induced changes in vagal nerve tone, stress response, and enteric environment [122]. The antimicrobial activity of certain alkaloids of $B$. caapi, including harmine and harmaline has been measured $[123,124]$ and this could contribute to alter the overall gut microbiota in using ayahuasca, although the relation of this effect on mental health seems difficult to assess. Recently, however, it has been suggested that low doses of psychedelics (micro-doses), which are sub-perceptual and therefore do not induce a psychedelic experience, may induce their psychological effects via alterations in the microbiome and related pathways to the brain [125]. Although the direct impact of ayahuasca on the gut microbiome remains unknown, it may play a role in the overall effects of this important traditional Amazonian medicine.

\section{Conclusion}

Recently, Fotiou and Gearing sought to create a dialogue between emic perspectives and studies that demonstrated how gut and brain share bi-directional flows of information, including stress and emotion [37]. This suggests how the biological relation between the gut and the brain echoes with the understandings of traditional practitioners and cross- cultural narratives of purging related to the expulsion of "negative things-including emotions- 


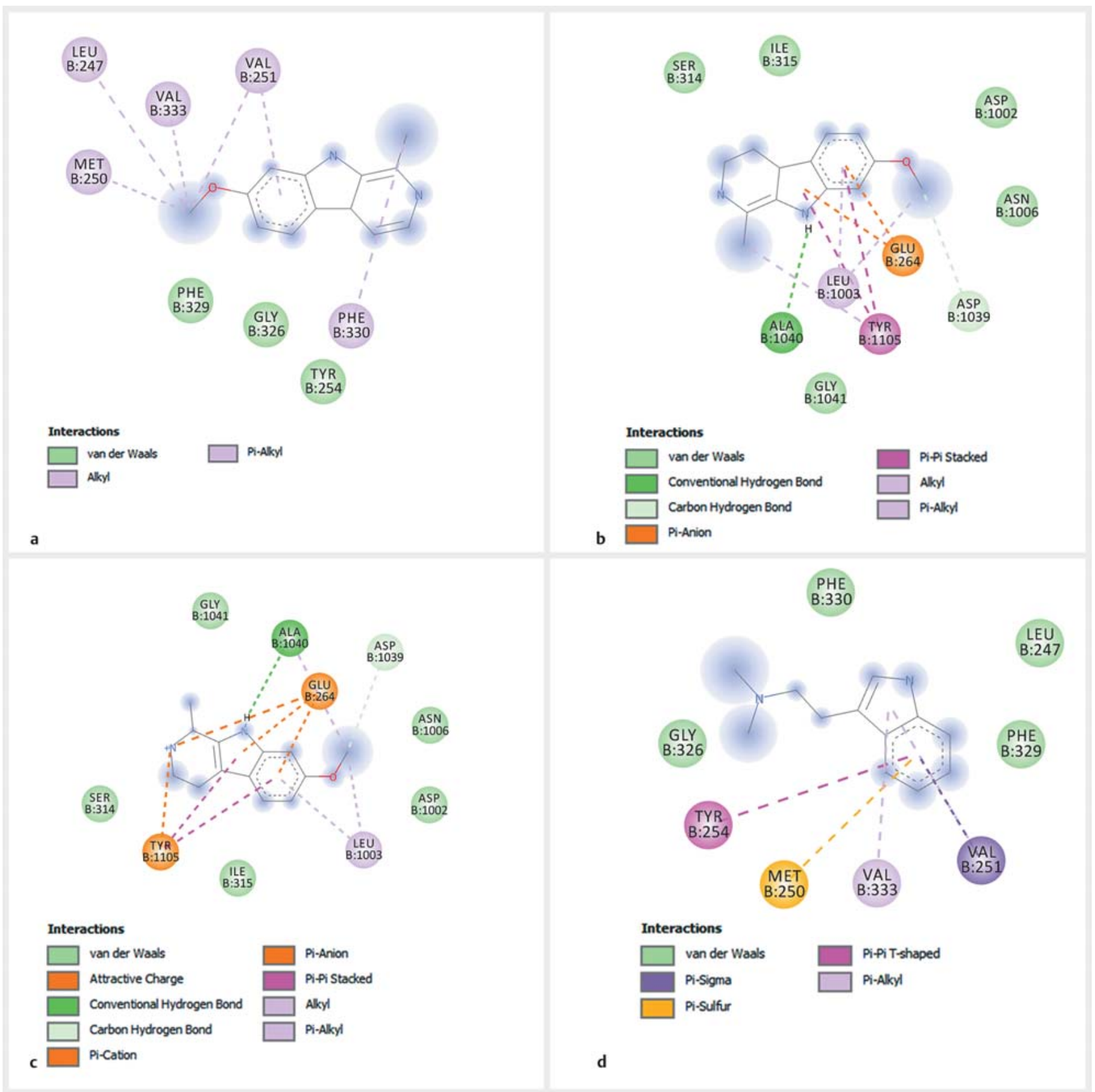

- Fig. 3 Putative interactions between harmine (a), harmaline (b), tetrahydroharmaline, (c) and N,N-dimethyltryptamine (d) with serotonin 5-HT2A receptor. The putative affinities were $28.9,24.4,12.4$, and $47.9 \mu \mathrm{M}$, respectively.

from the body", indicating that these perspectives should not be dismissed as having a purely symbolic valence. Moreover, it appears that from both indigenous and mestizo Amazonian contexts of study, the function of ayahuasca-related purgative and emetic effects are closely linked, if not inseparable, from the visionary and psychoactive ones; this seems fundamental even in the modern context of ayahuasca use.This is even though vomiting as a healing method is not relevant in the current Western healing culture, in contemporary neo-shamanic content of ayahuasca use, purging emerges as an essential and intrinsic aspect of its medicinal value.

The scientific stance has historically marginalized emic understandings of efficacy related to the plant world, confining them to the realm of belief, as part of a larger mechanization tendency of science and of a "colonial appropriation and marginalisation of indigenous knowledge" [126]. Validating ethnomedicines through a purely biochemical lens is often demeaning towards indigenous knowledge [127] and may lead to misunderstanding the basis of a plant's efficacy $[88,128]$. In this regard, interpreting the efficacy 
of a complex herbal preparation such as ayahuasca as the result of the effect of several chemical ingredients appears, in a way, an act of knowledge impoverishment. The traditional use of ayahuasca, in fact, implies a complex ceremony full of ritualism and, although still biochemically difficult to explain, it is already known that rituals may have an impact on a treatment efficacy $[129,130]$; as well, the placebo/nocebo effect is a well-known phenomenon in pharmacology, even though no drugs are involved [131]. Some of the authors (MP, LM, and CF) have recently contributed to research I focused on the impact of rituals and setting in psychedelic therapy ${ }^{4}$. One of the contributions, based on a large scale survey, confirms the relevance of the traditional context concerning the use of ayahuasca, stating that "aspects of setting (ceremonial practices and additional supports) and set (individual motivations) appear to have significant effects on users' acute experiences, the likelihood of experiencing difficulties with integration, and longer-term well-being and mental health outcomes" [132]. This indicates that non-pharmacological factors contribute to overall ayahuasca efficacy, and the very same act of vomiting and purging during an ayahuasca ceremony could also have a role in this regard, without any need for a comprehensive biochemical explanation. Within the current trend of psychedelics renaissance and psychedelics-assisted therapy programs $[133,134]$, a wideranging understanding of ethnomedicines should be therefore carefully taken into account and properly integrated; this is certainly true for ayahuasca, but probably applies to other psychoactive plant medicines.

In this context, the scientific validation of ayahuasca as an example of traditional medicine still used within the context of rational phytotherapy results in high complexity due to multiple factors that must be considered. The term refers to more than one plant species, often used in a mixture with different proportions, as well as the beverage obtained with a modern or traditional (and often unsettled) process. The obtained preparations, also characterized by the qualitative presence of phytochemicals, are used in traditional ceremony with holistic health-promoting effects as well as a modern hedonistic drug targeted for the recreational effects, as reflected by the un-harmonized scientific literature.

Although a full justification of the potential benefits of ayahuasca at the gastrointestinal level wasn't reached in this instance, both perspectives here presented, ethnocultural and pharmacological, clearly indicate a strong possibility in this regard; thus, suggesting further studies on this topic.

\section{Contributors' Statement}

Conception the study: M. Politi, L. Menghini; design of the work: M. Politi, G. Tresca, C. Ferrante; literature review on the cultural and anthropological aspects: G. Tresca; literature review and draft the phytochemical aspects: M. Politi, L. Menghini; literature review for pharmacological aspects: $C$. Ferrante; drafting the manuscript: M. politi; critical revision of the manuscript: M. Politi, C. Ferrante.

4 https://www.frontiersin.org/research-topics/13369/beyond-thepharmacology-of-psychoactive-plant-medicines-and-drugs-pros-andcons-of-the-role-of-ritua\#overview

\section{Acknowledgements}

The present study is also part of the third mission activities of the Botanic Garden "Giardino dei Semplici” planned for the 20th anniversary of the establishment.

Conflict of Interest

The authors declare that they have no conflict of interest.

References

[1] Miller MJ, Albarracin-Jordan J, Moore C, Capriles JM. Chemical evidence for the use of multiple psychotropic plants in a 1000-year-old ritual bundle from South America. Proc Natl Acad Sci U S A 2019; 116: 1120711212

[2] Ogalde JP, Arriaza BT, Soto EC. Identification of psychoactive alkaloids in ancient Andean human hair by gas chromatography/mass spectrometry. J Archaeol Sci 2009; 36: 467-472

[3] Frecska E, Bokor P, Winkelman M. The therapeutic potentials of ayahuasca: Possible effects against various diseases of civilization. Front Pharmacol 2016; 7: 35

[4] McKenna D]. Clinical investigations of the therapeutic potential of ayahuasca: Rationale and regulatory challenges. Pharmacol Ther 2004; 102: $111-129$

[5] Hamill J, Hallak J, Dursun SM, Baker G. Ayahuasca: Psychological and physiologic effects, pharmacology and potential uses in addiction and mental illness. Curr Neuropharmacol 2018; 17: 108128

[6] Domínguez-Clavé E, Soler J, Elices M, Pascual JC, Álvarez E, de la Fuente Revenga M, Friedlander P, Feilding A, Riba J. Ayahuasca: Pharmacology, neuroscience and therapeutic potential. Brain Res Bull 2016; 126: 89101

[7] Chi T, Gold JA. A review of emerging therapeutic potential of psychedelic drugs in the treatment of psychiatric illnesses. J Neurol Sci 2020; 411: 116715

[8] Kjellgren A, Eriksson A, Norlander T. Experiences of encounters with ayahuasca-"the vine of the soul". J Psychoactive Drugs 2009; 41: 309-315

[9] Brierley DI, Davidson C. Developments in harmine pharmacology Implications for ayahuasca use and drug-dependence treatment. Prog Neuro-Psychopharmacology Biol Psychiatry 2012; 39: 263-272

[10] Rodrigues AVSL, Almeida FJ, Vieira-Coelho MA. Dimethyltryptamine: Endogenous role and therapeutic potential. J Psychoactive Drugs 2019; 5: $299-310$

[11] Beyer SV. Singing to the Plants: A Guide to Mestizo Shamanism in the Upper Amazon. Albuquerque: University of New Mexico Press; 2011

[12] Pinkley HV. Plant admixtures to ayahuasca, the South American hallucinogenic drink. Lloydia 1969; 32: 305-314

[13] Rivier L, Lindgren JE. "Ayahuasca", the South American hallucinogenic drink: An ethnobotanical and chemical investigation. Econ Bot 1972; 26: $101-129$

[14] Politi M, Friso F, Saucedo G, Torres J. Traditional use of Banisteriopsis caapi alone and its application in a context of drug addiction therapy. J Psychoactive Drugs 2020; 53: 76-84

[15] Nagamine-Pinheiro N, Fagg CW, Gomes SM, Oliveira RC, SonsinOliveira J. Vegetative anatomy, morphology and histochemistry of three species of Malpighiaceae used in analogues of the Amazonian psychoactive beverage ayahuasca. Flora Morphol Distrib Funct Ecol Plants 2021; 275: 151760

[16] Gaujac A, Navickiene S, Collins MI, Brandt SD, de Andrade JB. Analytical techniques for the determination of tryptamines and $\beta$-carbolines in plant matrices and in psychoactive beverages consumed during religious 
ceremonies and neo-shamanic urban practices. Drug Test Anal 2012; 4: 636-648

[17] DeKorne J, Aardvark D, Trout K, eds. Ayahuasca Analogues and Plant Based Tryptamines (The Best of The Entheogen Review 1992-1999, ER Monograph Series No. 1). 2nd ed. Sacramento, CA: The Entheogen Review; 2000

[18] Ott J. Ayahuasca Analogues: Pangæan Entheogens. Kennewick, WA: Natural Books; 1994

[19] Kaasik H, Souza RCZ, Zandonadi FS, Tófoli LF, Sussulini A. Chemical composition of traditional and analog ayahuasca. J Psychoactive Drugs 2021; 53: 65-75

[20] McKenna DJ, Towers GHN, Abbott F. Monoamine oxidase inhibitors in South American hallucinogenic plants: Tryptamine and $\beta$-carboline constituents of ayahuasca. J Ethnopharmacol 1984; 10: 195-223

[21] Ott J. Pharmahuasca: Human pharmacology of oral DMT plus harmine. J Psychoactive Drugs 1999; 31: 171-177

[22] Prue R, Voss RW. Indigenous healing practice: Ayahuasca. Opening a discussion. J Pastoral Care Counsel 2014; 68: 6

[23] Luna LE. Indigenous and Mestizo Use of Ayahuasca. An Overview. In: dos Santos RG, ed. The Ethnopharmacology of Ayahuasca. Trivandrum: Transworld Research Network; 2011: 1-20

[24] Talin P, Sanabria E. Ayahuasca's entwined efficacy: An ethnographic study of ritual healing from 'addiction'. Int J Drug Policy 2017; 44: 23-30

[25] Politi M, Friso F, Mabit ]. Plant based assisted therapy for the treatment of substance use disorders - part 2. Beyond blurred counderies. Rev Cult y Drog 2019; 24: 19-42

[26] Politi M, Friso F, Mabit ]. Plant based assisted therapy for the treatment of substance use disorders - part 1 . The case of Takiwasi center and other similar experiences. Rev Cult y Drog 2018; 23: 99-126

[27] Loizaga-Velder A, Verres R. Therapeutic effects of ritual ayahuasca use in the treatment of substance dependence-Qualitative results. J Psychoactive Drugs 2014; 46: 63-72

[28] da Silva MG, Daros GC, de Bitencourt RM. Anti-inflammatory activity of ayahuasca: Therapeutical implications in neurological and psychiatric diseases. Behav Brain Res 2021; 400: 113003

[29] dos Santos RG, Osório FL, Crippa JAS, Hallak JEC. Antidepressive and anxiolytic effects of ayahuasca: A systematic literature review of animal and human studies. Rev Bras Psiquiatr 2016; 38: 65-72

[30] Jiménez-Garrido DF, Gómez-Sousa M, Ona G, Dos Santos RG, Hallak JEC, Alcázar-Córcoles MÁ, Bouso JC. Effects of ayahuasca on mental health and quality of life in naïve users: A longitudinal and cross-sectional study combination. Sci Rep 2020; 10: 4075

[31] dos Santos R, Bouso J, Hallak J, Alcazar-Corcoles M. Efficacy, tolerability, and safety of serotonergic psychedelics for the management of mood, anxiety, and substance-use disorders: a systematic review of systematic reviews. Expert Rev Clin Pharmacol 2018; 11: 889-902

[32] Orsolini L, Chiappini S, Papanti D, Latini R, Volpe U, Fornaro M, Tomasetti C, Vellante F, De Berardis D. How does ayahuasca work from a psychiatric perspective? Pros and cons of the entheogenic therapy. Hum Psychopharmacol 2020; 35: e2728

[33] Heise CW, Brooks DE. Ayahuasca exposure: Descriptive analysis of calls to US poison control centers from 2005 to 2015. J Med Toxicol 2017; 13: $245-248$

[34] Durante Í, dos Santos RG, Bouso JC, Hallak JE. Risk assessment of ayahuasca use in a religious context: self-reported risk factors and adverse effects. Braz J Psychiatry 2021; 43: 362-369. doi:10.1590/1516-44462020-0913

[35] Sanz-Biset J, Cañigueral S. Plants as medicinal stressors, the case of depurative practices in Chazuta valley (Peruvian Amazonia). J Ethnopharmacol 2013; 145: 67-76

[36] Mabit J. Ayahuasca in the treatment of addictions. In: Robert TB, Winkelman M], eds. Psychedelic Medicine: New Evidence for Hallucinogenic
Substances as Treatments. Santa Barbara: Greenwood Publishing Group; 2007: 87-103

[37] Fotiou E, Gearin AK. Purging and the body in the therapeutic use of ayahuasca. Soc Sci Med 2019; 239: 112532

[38] Luna LE. The concept of plants as teachers among four mestizo shamans of Iquitos, Northeastern Peru. J Ethnopharmacol 1984; 11: 135-156

[39] Shepard GH. Psychoactive plants and ethnopsychiatric medicines of the matsigenka. J Psychoactive Drugs 1998; 30: 321-332

[40] Rodriguez E, Cavin JC, West JE. The possible role of Amazonian psychoactive plants in the chemotherapy of parasitic worms - a hypothesis. J Ethnopharmacol 1982; 6: 303-309

[41] Luna LE. Vegetalismo: Shamanism Among the Mestizo Population of the Peruvian Amazon (Stockholm Studies in Comparative Religion). Stockolm: Almqvist \& Wiksell International; 1986

[42] Fotiou E. Working with "La Medicina": Elements of healing in contemporary ayahuasca rituals. Anthropol Conscious 2012; 23: 6-27

[43] Mabit J, Giove R, Vega J. The Use of Amazonian Shamanism to rehabilitate Drug Addicts. In: Andritzky W, ed. Yearbook of Cross-Cultural Medicine and Psychotherapy. Berlin: VWB - Verlag für Wissenschaft und Bildung; 1996: 257-285

[44] Shepard GH. Venenos divinos: Plantas psicoativas dos Matsigenka do Peru. In: Labate B, Goulart S, eds. O Uso Ritual Das Plantas de Poder. São Paulo: Mercado de Letras; 2005: 187-217

[45] De Feo V. Ethnomedical field study in northern Peruvian Andes with particular reference to divination practices. J Ethnopharmacol 2003; 85: $243-256$

[46] Jauregui X, Clavo ZM, Jovel EM, Pardo-De-Santayana M. “Plantas con madre": Plants that teach and guide in the shamanic initiation process in the East-Central Peruvian Amazon. J Ethnopharmacol 2011; 134: 739752

[47] Labate BC. The Internationalization of Peruvian Vegetalismo. In: Labate BC, Cavnar C, eds. Ayahuasca Shamanism in the Amazon and Beyond. NewYork: Oxford University Press; 2014: 183-205

[48] Fotiou E. The globalization of ayahuasca shamanism and the erasure of indigenous shamanism. Anthropol Conscious 2016; 27: 151-179

[49] Gearin AK, Labate BC. "La dieta”: Ayahuasca and the Western Reinvention of Indigenous Amazonian Food Shamanism. In: Labate BC, Cavnar C, eds. The Expanding World Ayahuasca Diaspora: Appropriation, Integration and Legislation. London: Routledge; 2018: 177-198

[50] Schmid JT, Jungaberle H, Verres R. Subjective theories about (self-) treatment with ayahuasca. Anthropol Conscious 2010; 21: 188-204

[51] Gearin A. Dividual vision of the individual: Ayahuasca neo-shamanism in Australia and the new age individualism orthodoxy. Int J Study New Relig 2016; 7: 199-220

[52] Apud I. Ayahuasca from Peru to Uruguay: Ritual design and redesign through a distributed cognition approach. Anthropol Conscious 2015; 26: $1-27$

[53] Berlowitz I, Ghasarian C, Walt H, Mendive F, Alvarado V, Martin-Soelch C. Conceptions and practices of an integrative treatment for substance use disorders involving Amazonian medicine: Traditional healers' perspectives. Rev Bras Psiquiatr 2018; 40: 200-209

[54] Souza RCZ, Zandonadi FS, Freitas DP, Tófoli LFF, Sussulini A. Validation of an analytical method for the determination of the main ayahuasca active compounds and application to real ayahuasca samples from Brazil. J Chromatogr B Anal Technol Biomed Life Sci 2019; 1124: 197-203

[55] Lo Faro AF, Di Trana A, La Maida N, Tagliabracci A, Giorgetti R, Busardò FP. Biomedical analysis of new psychoactive substances (NPS) of natural origin. J Pharm Biomed Anal 2020; 179: 112945

[56] Lesiak AD, Musah RA. Application of ambient ionization high resolution mass spectrometry to determination of the botanical provenance of the constituents of psychoactive drug mixtures. Forensic Sci Int 2016; 266: $271-280$ 
[57] Chambers MI, Appley MG, Longo CM, Musah RA. Detection and quantification of psychoactive N,N-dimethyltryptamine in ayahuasca brews by ambient ionization high-resolution mass spectrometry. ACS Omega 2020; 5: 28547-28554

[58] Wang YH, Samoylenko V, Tekwani BL, Khan IA, Miller LS, Chaurasiya ND, Rahman MM, Tripathi LM, Khan SI, Joshi VC, Wigger FT, Muhammad I. Composition, standardization and chemical profiling of Banisteriopsis caapi, a plant for the treatment of neurodegenerative disorders relevant to Parkinson's disease. J Ethnopharmacol 2010; 128: 662-671

[59] Yritia M, Riba J, Ortuño J, Ramirez A, Castillo A, Alfaro Y, de la Torre R, Barbanoj MJ. Determination of $\mathrm{N}, \mathrm{N}$-dimethyltryptamine and $\beta$-carboline alkaloids in human plasma following oral administration of ayahuasca. J Chromatogr B Anal Technol Biomed Life Sci 2002; 779: 271-281

[60] Silveira GO, Lourenço FR, Bruno V, Yonamine M. Fast hollow fiber liquidphase microextraction as a greener alternative for the determination of $\mathrm{N}, \mathrm{N}$-dimethyltryptamine and harmala alkaloids in human urine. Front Chem 2020; 8: 558501

[61] Callaway JC, Brito GS, Neves ES. Phytochemical analyses of banisteriopsis caapi and psychotria viridis. J Psychoactive Drugs 2005; 37: 145-150

[62] Santos BWL, de Oliveira RC, Sonsin-Oliveira J, Fagg CW, Barbosa JBF, Caldas ED. Biodiversity of $\beta$-carboline profile of banisteriopsis caapi and ayahuasca, a plant and a brew with neuropharmacological potential. Plants 2020; 9: 870

[63] Labate BC, Macrae E, Goulart S, eds. Brazilian Ayahuasca Religions in Perspective. In: Ayahuasca, Ritual and Religion in Brazil. London: Taylor and Francis; 2016: 1-20

[64] Callaway JC. Various alkaloid profiles in decoctions of banisteriopsis caapi. J Psychoactive Drugs 2005; 37: 151-155

[65] Huhn C, Neusüß C, Pelzing M, Pyell U, Mannhardt J, Pütz M. Capillary electrophoresis-laser induced fluorescence-electrospray ionization-mass spectrometry: A case study. Electrophoresis 2005; 26: 1389-1397

[66] Pires APS, De Oliveira CDR, Moura S, Dörr FA, Silva WAE, Yonamine M. Gas chromatographic analysis of dimethyltryptamine and $\beta$-carboline alkaloids in ayahuasca, an Amazonian psychoactive plant beverage. Phytochem Anal 2009; 20: 149-153

[67] Gambelunghe C, Aroni K, Rossi R, Moretti L, Bacci M. Identification of $\mathrm{N}, \mathrm{N}$-dimethyltryptamine and $\beta$-carbolines in psychotropic ayahuasca beverage. Biomed Chromatogr 2008; 22: 1056-1059

[68] Mcllhenny EH, Pipkin KE, Standish L], Wechkin HA, Strassman R, Barker SA. Direct analysis of psychoactive tryptamine and harmala alkaloids in the Amazonian botanical medicine ayahuasca by liquid chromatography-electrospray ionization-tandem mass spectrometry. J Chromatogr A 2009; 1216: 8960-8968

[69] Estrella-Parra EA, Almanza-Pérez JC, Alarcón-Aguilar FJ. Ayahuasca: Uses, phytochemical and biological activities. Nat Products Bioprospect 2019; 9: 251-265

[70] Soares DBS, Duarte LP, Cavalcanti AD, Silva FC, Braga AD, Lopes MTP, Takahashi JA, Vieira-Filho SA. Psychotria viridis: Chemical constituents from leaves and biological properties. An Acad Bras Cienc 2017; 89: 927-938

[71] Simão AY, Gonçalves J, Gradillas A, García A, Restolho J, Fernández N, Rodilla JM, Barroso M, Duarte AP, Cristóvão AC, Gallardo E. Evaluation of the cytotoxicity of ayahuasca beverages. Molecules 2020; 25: 5594

[72] Gonçalves ], Luís Â, Gradillas A, García A, Restolho J, Fernández N, Domingues F, Gallardo E, Duarte AP. Ayahuasca beverages: Phytochemical analysis and biological properties. Antibiotics 2020; 9: 731

[73] Santos MC, Navickiene S, Gaujac A. Determination of tryptamines and $\beta$ carbolines in ayahuasca beverage consumed during Brazilian religious ceremonies. J AOAC Int 2017; 100: 820-824

[74] Luna LE. The healing practices of a Peruvian shaman. J Ethnopharmacol 1984; 11: 123-133
[75] Jernigan KA. Dietary restrictions in healing among speakers of Iquito, an endangered language of the Peruvian Amazon. J Ethnobiol Ethnomed 2011; 7: 20

[76] Sanz-Biset J, Cañigueral S. Plant use in the medicinal practices known as "strict diets" in Chazuta valley (Peruvian Amazon). J Ethnopharmacol 2011; 137: 271-288

[77] O'Shaughnessy DM, Berlowitz I. Amazonian medicine and the psychedelic revival: Considering the "Dieta". Front Pharmacol 2021; 12: 639124

[78] Politi M, Rumlerova T, Rojas GS, Rumlerova T, Marcus O, Romero JT, Mabit J. Medicinal plants diet as emerging complementary therapy from the Amazonian tradition. Data from Centro Takiwasi, a Peruvian therapeutic community. J Med Herbs Ethnomedicine 2019; 5: 23-28

[79] Fotiou E. Technologies of the body in contemporary ayahuasca shamanism in the Peruvian Amazon: Implications for future research. Hum Ecol 2019; 47: 145-151

[80] Cholewka C, Friso F, Politi M. The use of plants diet in traditional Amazonian medicine: Implications for a new approach in herbal medicine. Phytotherapie 2020; 18: 169-179

[81] Parise AG, Gagliano M, Souza GM. Extended cognition in plants: Is it possible? Plant Signal Behav 2020; 15: 1710661

[82] Calvo P, Gagliano M, Souza G, Trewavas A. Plants are intelligent, here's how. Ann Bot 2020; 125: 11-28

[83] Baluška F, Mancuso S. Plants, climate and humans: Plant intelligence changes everything. EMBO Rep 2020; 21: e50109

[84] Attala L. "The Edibility Approach": Using edibility to explore relationships, plant agency and the porosity of species' boundaries. Adv Anthropol 2017; 7: 125-145

[85] Wu X, Wang S, Lu J, Jing Y, Li M, Cao J, Bian B, Hu C. Seeing the unseen of Chinese herbal medicine processing (Paozhi): Advances in new perspectives. Chin Med 2018; 13: 4

[86] Liu S, Li F, Li Y, Li W, Xu J, Du H. A review of traditional and current methods used to potentially reduce toxicity of Aconitum roots in Traditional Chinese Medicine. J Ethnopharmacol 2017; 207: 237-250

[87] Politi M, Tresca G, Soffiato M, Garay-Montes R, Mendive F. Phytochemica profiling of Amazonian herbal medicinal products: The role of traditional processing methods. J Med Herbs Ethnomedicine 2019; 5: 1-7

[88] Tresca G, Marcus O, Politi M. Evaluating herbal medicine preparation from a traditional perspective: Insights from an ethnopharmaceutical survey in the Peruvian Amazon. Anthropol Med 2020; 27: 268-284

[89] Popa SL, Chiarioni G, David L, Golea GI, Dumitrascu DL. Functional emesis. J Gastrointest Liver Dis 2019; 28: 319-325

[90] Keel PK. Purging disorder: Recent advances and future challenges. Curr Opin Psychiatry 2019; 32: 518-524

[91] Chai D, Jiang H, Li Q. Induced vomiting: A therapeutic option. Int J Clin Exp Med 2016; 9: 17098-17105

[92] Rastogi S. Effectiveness, safety, and standard of service delivery: A patient-based survey at a pancha karma therapy unit in a secondary care Ayurvedic hospital. J Ayurveda Integr Med 2011; 2: 197-204

[93] Barrett ME. Wat Thamkrabok: A Buddhist drug rehabilitation program in Thailand. Subst Use Misuse 1997; 32: 435-459

[94] Yuen H, Hong Yang AW, Hung A, Lenon GB. How does traditional knowledge of Cassiae semen shed light on weight management? - A classical and modern literature review. J Ethnopharmacol 2021; 268: 113572

[95] Numata T, Sato-Numata K, Okada Y. Herbal components of Japanese Kampo medicines exert laxative actions in colonic epithelium cells via activation of BK and CFTR channels. Sci Rep 2019; 9: 15554

[96] Junior VH, Martins IA. KAMBÔ: an Amazonian enigma. J Venom Res 2020; 10: 13-17

[97] Berlowitz I, Torres EG, Walt H, Wolf U, Maake C, Martin-Soelch C. "Tobacco is the chief medicinal plant in my work": Therapeutic uses of tobacco in Peruvian Amazonian medicine exemplified by the work of a maestro tabaquero. Front Pharmacol 2020; 11: 1 
[98] Kravetz RE. Tobacco enema. Am J Gastroenterol 2002; 97: 2453-2453

[99] Valassi E, Scacchi M, Cavagnini F. Neuroendocrine control of food intake. Nutr Metab Cardiovasc Dis 2008; 18: 158-168

[100] Strassman RJ. Adverse reactions to psychedelic drugs. A review of the literature. J Nerv Ment Dis 1984; 172: 577-595

[101] Brito-da-Costa A, Dias-da-Silva D, Gomes N, Dinis-Oliveira R, Madureira-Carvalho A. Toxicokinetics and toxicodynamics of Ayahuasca alkaloids N, N-Dimethyltryptamine (DMT), harmine, harmaline and tetrahydroharmine: clinical and forensic impact. Pharmaceuticals (Basel) 2020; 13: 1-39

[102] Cameron L, Olson D. Dark classics in chemical neuroscience: N,N-Dimethyltryptamine (DMT). ACS Chem Neurosci 2018; 9: 2344-2357

[103] Sanches R, de Lima Osório F, Dos Santos R, Macedo L, Maia-de-Oliveira J, Wichert-Ana L, de Araujo D, Riba J, Crippa J, Hallak J. Antidepressant effects of a single dose of Ayahuasca in patients with recurrent depression: A SPECT study. J Clin Psychopharmacol 2016; 36: 77-81

[104] Brown C, Mehler P. Medical complications of self-induced vomiting. Eat Disord 2013; 21: 287-294

[105] Phipps SM, Grundmann O. Pharmacology and Structure-Activity Relationship of natural Products with psychoactive Effects from Salvia divinorum, Mitragyna speciosa, and ayahuasca. In: Atta-ur-Rahman, ed. Studies in Natural Products Chemistry. Amsterdam: Elsevier; 2017: 144

[106] Riba J, Valle M, Urbano G, Yritia M, Morte A, Barbanoj M]. Human pharmacology of ayahuasca: Subjective and cardiovascular effects, monoamine metabolite excretion, and pharmacokinetics. J Pharmacol Exp Ther 2003; 306: 73-83

[107] Moloudizargari M, Mikaili P, Aghajanshakeri S, Asghari M, Shayegh J. Pharmacological and therapeutic effects of Peganum harmala and its main alkaloids. Pharmacogn Rev 2013; 7: 199-212

[108] Lanaro R, Calemi DB, Togni LR, Costa JL, Yonamine M, Cazenave SOS, Linardi A. Ritualistic use of ayahuasca versus street use of similar substances seized by the police: A key factor involved in the potential for intoxications and overdose? J Psychoactive Drugs 2015; 47: 132-139

[109] Frison G, Favretto D, Zancanaro F, Fazzin G, Ferrara SD. A case of $\beta$-carboline alkaloid intoxication following ingestion of Peganum harmala seed extract. Forensic Sci Int 2008; 179: e37-43

[110] Martin-Gronert MS, Stocker C], Wargent ET, Cripps RL, Garfield AS, Jovanovic Z, D'Agostino G, Yeo GSH, Cawthorne MA, Arch JRS, Heisler LK, Ozanne SE. 5-HT2A and 5-HT2C receptors as hypothalamic targets of developmental programming in male rats. DMM Dis Model Mech 2016; 9: 401-412

[111] Demirbugen OM, Uckun Z, Yuce-Artun N, Baskak B, Ozdemir H, Kizil Ozel T, Devrimci Ozguven H, Suzen HS. The relationship between the serotonin $2 \mathrm{~A}$ receptor gene $-1438 \mathrm{~A} / \mathrm{G}$ and $102 \mathrm{~T} / \mathrm{C}$ polymorphisms and citalopram/sertraline-induced nausea in major depressed patients. Hum Psychopharmacol 2018; 33: e2673

[112] Wolff MC, Leander JD. A comparison of the behavioural effects of 5$\mathrm{HT} 2 \mathrm{~A}$ and $5-\mathrm{HT} 2 \mathrm{C}$ receptor agonists in the pigeon. Behav Pharmacol 2000; 11: 355-364

[113] Wu Q, Kuca K, Nepovimova E, Wu W. Type a trichothecene diacetoxyscirpenol-induced emesis corresponds to secretion of peptide yy and serotonin in mink. Toxins (Basel) 2020; 12: 419

[114] Kannen V, Bader M, Sakita JY, Uyemura SA, Squire JA. The dual role of serotonin in colorectal cancer. Trends Endocrinol Metab 2020; 31: 611-625

[115] Orlando G, Recinella L, Chiavaroli A, Brunetti L, Leone S, Carradori S, Di Simone S, Ciferri MC, Zengin G, Ak G, Abdullah HH, Cordisco E, Sortino M, Svetaz L, Politi M, Angelini P, Covino S, Venanzoni R, Cesa S, Menghini L, Ferrante $C$. Water extract from inflorescences of industrial hemp futura 75 variety as a source of anti-inflammatory, anti-proliferative and antimycotic agents: Results from in silico, in vitro and ex vivo studies. Antioxidants 2020; 9: 437
[116] Ferrante C, Recinella L, Ronci M, Orlando G, Di Simone S, Brunetti L, Chiavaroli A, Leone S, Politi M, Tirillini B, Angelini P, Covino S, Venanzoni R, Vladimir-Knežević S, Menghini L. Protective effects induced by alcoholic Phlomis fruticosa and Phlomis herba-venti extracts in isolated rat colon: Focus on antioxidant, anti-inflammatory, and antimicrobial activities in vitro. Phyther Res 2019; 33: 2387-2400

[117] Bouso JC, González D, Fondevila S, Cutchet M, Fernández X, Ribeiro Barbosa PC, Alcázar-Córcoles MÁ, Araújo WS, Barbanoj MJ, Fábregas JM, Riba J. Personality, psychopathology, life attitudes and neuropsychological performance among ritual users of ayahuasca: A longitudinal study. PLoS One 2012; 7: e42421

[118] Sampedro F, Revenga MDLF, Valle M, Roberto N, Domínguez-Clavé E, Elices M, Luna LE, Crippa JAS, Hallak JEC, Araujo DBD, Friedlander P, Barker SA, Álvarez E, Soler J, Pascual JC, Feilding A, Riba J. Assessing the psychedelic "after-glow" in ayahuasca users: Post-acute neurometabolic and functional connectivity changes are associated with enhanced mindfulness capacities. Int ] Neuropsychopharmacol 2017; 20: 698-711

[119] Hery F, Hamon M. Neuroleptics and serotonin. Encephale 1993; 19 : 525-532

[120] Maiuolo J, Gliozzi M, Musolino V, Carresi C, Scarano F, Nucera S, Scicchitano M, Oppedisano F, Bosco F, Ruga S, Zito MC, Macri R, Palma E, Muscoli C, Mollace V. The contribution of gut microbiota-Brain axis in the development of brain disorders. Front Neurosci 2021; 15: 616883

[121] Strandwitz P. Neurotransmitter modulation by the gut microbiota. Brain Res 2018; 1693: 128-133

[122] Thompson C, Szabo A. Psychedelics as a novel approach to treating autoimmune conditions. Immunol Lett 2020; 228: 45-54

[123] Ahmad A, Khan K, Sultana S, Siddiqui B, Begum S, Faizi S, Siddiqui S Study of the in vitro antimicrobial activity of harmine, harmaline and their derivatives. J Ethnopharmacol 1992; 35: 289-294

[124] Salman S, Idrees F, Pervaiz S, Shah FH, Badshah S, Usman M, Halimi SA, Idrees ], Wali Khan A. Evaluation of antimicrobial activities of harmine, harmaline, nicotine and their complexes. Pak J Pharm Sci 2016; 29: $1317-1320$

[125] Kuypers KPC. Psychedelic medicine: The biology underlying the persisting psychedelic effects. Med Hypotheses 2019; 125: 21-24

[126] Dev L. Plant Knowledges: Indigenous Approaches and Interspecies lis tening toward decolonizing Ayahuasca Research. In: Labate B, Cavnar C, eds. Plant Medicines, Healing and Psychedelic Science: Cultural Perspectives. Cham: Springer; 2018: 185-204

[127] Reyes-García V. The relevance of traditional knowledge systems for ethnopharmacological research: Theoretical and methodological contributions. J Ethnobiol Ethnomed 2010; 6: 32

[128] Etkin NL. Cultural Constructions of Efficacy. In: VanDerGeest S, Whyte SR, eds. The Context of Medicines in Developing Countries: Studies in Pharmaceutical Anthropology. Dordrecht: Kluwer Academic Publishers; 1988: 299-327

[129] Legare C, Souza A. Evaluating ritual efficacy: Evidence from the supernatural. Cognition 2012; 124: 1-15

[130] Quack J, Sax WS. Introduction: The efficacy of rituals. J Ritual Stud 2010; 24: 5-12

[131] Požgain I, Požgain Z, Degmečić D. Placebo and nocebo effect: A minireview. Psychiatr Danub 2014; 26: 100-107

[132] Perkins D, Schubert V, Simonová H, Tófoli LF, Bouso JC, Horák M Galvão-Coelho NL, Sarris J. Influence of context and setting on the mental health and wellbeing outcomes of Ayahuasca drinkers: Results of a large international survey. Front Pharmacol 2021; 12: 623979

[133] Nutt D. Psychedelic drugs-a new era in psychiatry? Dialogues Clin Neurosci 2019; 21: 139-147

[134] Reiff CM, Richman EE, Nemeroff CB, Carpenter LL, Widge AS, Rodriguez Cl, Kalin NH, McDonald WM. Psychedelics and psychedelicassisted psychotherapy. Am J Psychiatry 2020; 177: 391-410 